\title{
Effect of some Neuroprotective drugs on certain biochemical parameters during experimental brain ischaemia.
}

\author{
Abdel-Aal, M., Zakaria, M.N., EL-Fayoumi, M.M., and Oraby, M.A. \\ Department of Pharmacology, Faculty of Pharmacy, Zagazig University, Egypt.
}

\begin{abstract}
Cerebral ischaemia reperfusion (I/R) triggers a complex series of biochemical events that lead to formation of reactive oxygen species (ROS) and the impairment of enzymatic mechanisms, which result in tissue oxidative stress. This study investigated the effect of some neuroprotective drugs such as vinpocetine, cinnarizine, pyritinol, and rosiglitazone on oxidative stress and cell death biomarkers occurred during experimental brain ischemia/reperfusion injury in rats. Adult male albino Wistar rats were subjected to $1 \mathrm{hr}$ of brain ischaemia followed by reperfusion for $2 \mathrm{hr}$. Rats were orally treated with aqueous suspension of vinpocetine $(3 \mathrm{mg} / \mathrm{kg})$, cinnarizine $(7 \mathrm{mg} / \mathrm{kg})$, pyritinol $(55 \mathrm{mg} / \mathrm{kg})$, and rosiglitazone $(0.5 \mathrm{mg} / \mathrm{kg})$, after $1 \mathrm{hr}$ of ischaemia. Brain superoxide dismutase (SOD), glutathione (GSH), and malondialdhyde (MDA) contents and serum nitric oxide (NO), lactate dehydrogenase (LDH), catalase (CAT), and glucose-6-phosphate dehydrogenase (G6PDH) levels were quantified at the end of the experiment. I/R injury caused a significant decrease in the activity of brain SOD, GSH contents and serum CAT level. It caused a significant increase in serum NO, LDH, G6PDH levels, and brain MDA content in comparison with the sham-operated group. Vinpocetine and rosiglitazone reversed all these biochemical indices. Pyritinol reversed all these biochemical indices except serum NO, and G6PDH. Cinnarizine could not affect brain MDA, serum NO and CAT levels. Both vinpocetine and rosiglitazone may be potent neuroprotective agents against experimental brain I/R injury in rats. Cinnarzine and pyritinol showed a marked neuroprotective activity but less than both drugs.
\end{abstract}

Key words: Vinpocetine, Rosiglitazone, Cinnarizine, Pyritinol, Ischaemia /Reperfusion.

\section{INTRODUCTION}

Acute ischaemic stroke is the third leading cause of death in industrialized countries (Lo et al., 2003) and the most frequent cause of permanent disability in adults worldwide. In the western world, over $70 \%$ of individuals experiencing a stroke are over 65 years of age (Donnan et al., 2008). The most common cause of stroke is the sudden occlusion of a blood vessel by a thrombus or embolism, resulting in an almost immediate loss of oxygen and glucose to the cerebral tissue due to loss of blood circulation, resulting in a corresponding loss of neurological function. In most cases, the cause is atherothrombosis of large cervical or intracranial arteries, or embolism from the heart. Deficits can include partial paralysis, difficulties with memory, thinking, language, and movement. Within seconds to minutes after the loss of blood flow to a region of the brain, the ischaemic cascade is rapidly initiated, which comprises a series of subsequent biochemical events that eventually lead to disintegration of cell membranes and neuronal death at the center / core of the infarction. Ischaemic stroke begins with severe focal hypoperfusion that leads to excitotoxicity and oxidative damage which in turn cause microvascular injury, blood brain barrier dysfunction and initiate post-ischaemic inflammation. These events all exacerbate the initial injury and can lead to permanent cerebral damage (Lakhan et al., 2009).

Two principal types of clinical cerebral ischaemia are recognized, focal and global cerebral ischaemia. Focal cerebral ischaemia occurs when a 
reduction or cessation of blood flow to a localized area of the brain, and occurs due to large-vessel disease (such as embolic or thrombotic arterial occlusion, often in a setting of atherosclerosis) or to small-vessel disease (such as vasculitis). Focal ischaemia may also accompany other acute brain insults, such as intracerebral haemorrhage or trauma (Dugan \& choi, 1999; Traystman, 2003; and Frosch et al., 2005). Whereas, global cerebral ischaemia occurs when there is a generalized reduction of cerebral perfusion. It occurs in cases such as cardiac arrest, shock, and severe hypotension. Various animal models have been developed to investigate the pathophysiology and treatment of cerebral ischaemia (Ginsberg \& Busto, 1989; and Ahmed et al., 2000). The use of animals rather than humans in the study of ischaemic injury has the advantage of the feasibility to be physiologically controlled so that the resulting injury is reproducible and variability is also limited as possible. These models also allow careful dissection of potential mechanisms of injury and neuroprotection and take in consideration timing of the events that occur after the ischaemic insult. However, it should be clearly understood that none of these models exactly mimics cerebral ischaemia in humans (Dietrich, 1998; and Traystman, 2003).

Vinpocetine which is related to the Vinca minor alkaloid vincamine is a potent neuroprotective agent for the prevention and treatment of central nervous disorders of cerebrovascular origin. Its beneficial clinical effects are based on a wide range of mechanisms including antioxidant, vasodilating and neuroprotective effects (Bönöczk et al., 2000; and Vas \& Gulyás, 2005). It has a well documented effect on cerebral glucose metabolism and blood flow (Tretter \& Adam-Vizi, 1998). Cinnarizine is a piperazine derivative first used as antihistaminic. Later on, it was found to have a sedative as well as a peripheral antivasoconstrictor. It is a selective $\mathrm{Ca}^{2+}$ channel blocker that widely used in the treatment of cerebral and vascular insufficiency (Singh, et al., 1985). It has been shown to protect isolated perfused rat liver against warm ischaemia and reperfusion (Konrad et al., 1995) and also to be neuroprotective (De Haan et al., 1993; and Gunn et al., 1994).

Pyritinol is a nootropic drug (cognition-enhancing agent) used in cognitive disturbances to improve cerebral functions. It is a potent scavenger of hydroxyl free radicals and the antioxidant properties of the drug are responsible for many of the benefits of pyritinol (Genkova-Papazova et al., 1994). It is useful in protecting brain cells from hypoxia, aiding recovery from head injury and stroke (Jaiswal et al., 1990; Toledano \& Bentura, 1994; and Stoppe et al., 1995).

Thiazolidinediones are used clinically as insulin sensitizers to treat type 2 diabetes. However, it is known that various thiazolidinediones provide a potent protective effect against ischaemic/reperfusion injury of the heart and other peripheral organs by attenuating the inflammatory response (Nakajima et al., 2001; Yue et al., 2001; Okada et al., 2002; and Wayman et al., 2002). Rosiglitazone, the most potent thiazolidinedione for PPAR- $\gamma$ activation, markedly decreased brain injury after focal ischaemia and reperfusion, and this neuroprotective effect of rosiglitazone is attributed at least in part to its antiinflammatory actions (Fahmi et al., 2001; and Luna-Medina et al., 2005). It may exert beneficial vascular effects by decreasing oxidative stress (Calkin et al., 2005).

\section{AIM OF THE WORK}

The present study is designed to investigate the effects of different drug classes with different mechanisms of action against experimental brain ischaemia/reperfusion injury in rats 


\section{MATERIALS and METHODS}

1. Animals: Adult male albino rats of Wistar strain weighing 180-250 g were used in this study. They were obtained from the animal house of Faculty of Pharmacy, Zagazig University. They were allowed free access to water and pelleted standard rat chow diet ad libitium and left for an initial adaption period of one week before any experimental manipulation. Animals were fasted for 18 hours before surgery, but allowed free access to water. All experimental procedures were approved by the ethical committee for animal handling at Zagazig Univeristy (ECAHZU).

2. Induction of brain ischaemia: Brain ischaemia was induced in rats according to the method of Vanella et al. (1990). Rats were anaesthetized with i.p. injection of urethane $(1.3 \mathrm{~g} / \mathrm{kg})$. A midline incision was made in the neck and both common carotid arteries were exposed and carefully freed from the surrounding tissues and autonomic innervation. Blood flow through both carotid arteries was interrupted by their clamping using removable miniclips for one hour. Reperfusion is done by declamping of both carotid arteries for $2 \mathrm{hr}$ allowing the blood to recirculate. Temperature was maintained during the experiment using a heat lamp placed above the head of the animal to avoid cerebral hypothermia which protects brain against ischaemic injury (Seif-ElNasr et al., 1992).

3. Classification of animals: The rats were divided into 6 groups (7 in each). The first is the ischaemic group in which rats were subjected to $1 \mathrm{hr}$ of brain ischaemia then reperfusion for $2 \mathrm{hr}$. The second is the sham-operated control group in which the rats were anaesthetized and subjected to all surgical manipulations without occlusion of the carotid arteries. Then the 4 group were randomly distributed and received a freshly prepared aqueous suspension of vinpocetine (3 $\mathrm{mg} / \mathrm{kg})$, cinnarizine (7 $\mathrm{mg} / \mathrm{kg})$, pyritinol $(55 \mathrm{mg} / \mathrm{kg})$, and rosiglitazone $(0.5 \mathrm{mg} / \mathrm{kg})$, administered orally after one hour of brain ischaemia.

\section{Preparation of tissue and serum} samples: At the end of the reperfusion period, rats were sacrificed by decapitation. Skulls were split on ice and the whole brain of each animal was rapidly isolated, washed with ice cold saline, blotted dry and weighed. Then the brain was homogenized in ice cold bidistilled water using Teflon homogenizer (Glas-Col homogenizer, Terre Haute, USA). Homogenization was carried out in an ice chilled glass homogenizing cup for three periods each of 5 seconds to avoid overheating of the tissue. The brain homogenate was divided into three aliquot. The first aliquot of $0.5 \mathrm{ml}$ of the homogenate was mixed with $1 \mathrm{ml}$ ice cold $5 \%$ sulfosalicylic acid solution (Abd-ElGawad and El-Sawalhi, 2004) and left in an ice bath for complete precipitation for about 2 hours. The tubes were then centrifuged at $2500 \mathrm{xg}$ for 30 minutes at $4 \circ \mathrm{C}$ and the supernatant was used for (GSH) analysis. The second aliquot of one $\mathrm{ml}$ of the homogenate was mixed with $1 \mathrm{ml}$ ice cold $2.3 \% \mathrm{KCl}$ solution and centrifuged at $600 \mathrm{xg}$ for 20 minutes at $4^{\circ}$ $\mathrm{C}$ to remove the cell debris and the supernatant was used for MDA analysis (Uchiyama and Mihara, 1978). The third aliquot of $0.5 \mathrm{ml}$ of the homogenate was diluted in ice-cold $0.25 \mathrm{M}$ sucrose to approximately $10 \% \mathrm{w} / \mathrm{v}$ and centrifuged at $4000 \mathrm{rpm}$ for 10 minutes at $4^{\circ} \mathrm{C}$ and the supernatant was used for (SOD) analysis (Nishikimi et al., 1972). Blood samples were collected, in clean dry centrifuge tubes, from the retro-orbital plexus using microcapillary tubes as described by Sorg and Buker, (1964). The tubes were refrigerated for 15 minutes to coagulate, and then centrifuged at 4500 for 30 minutes. Serum was collected and frozen at $-20^{\circ} \mathrm{C}$ until analysis. Serum CAT level was 
assayed colorimetrically by the method of Johansson and Borg, (1988). Serum Nitrite (NO) was determined using a colorimetric method as described by Montgomery and Dymock, (1961). Serum (LDH) was determined using a fixed rate kinetic method as described by Pesce, (1984). Serum (G6PDH) was assayed spectrophotomerticaly by the method of Kornberg and Horecker, (1955).

\section{Statistical analysis:}

Results were represented as mean \pm standard deviation of the mean (S.D.M). Results were statistically analyzed by one-way analysis of variance (ANOVA) with multiple comparisons using posthoc analysis and differences were considered significant at $p<0.05$.

\section{RESULTS}

1. Effect on the activity of brain superoxide dismutase (SOD), and glutathione (GSH) contents:

The results of the present study showed that, ischaemia/reperfusion induced a significant decrease in the activity of brain SOD and GSH contents compared to the sham-operated group. Brain SOD activity was $28.9 \pm 4.3 \mathrm{u} / \mathrm{g}$ in the ischaemic group vs $44.6 \pm 5.1 \mathrm{u} / \mathrm{g}$ in the sham-operated group and Brain GSH activity was $22.1 \pm 6.5 \mu \mathrm{mol} / \mathrm{g}$ in the ischaemic group vs $38.1 \pm 14.4 \mu \mathrm{mol} / \mathrm{g}$ in the sham-operated group. Administration of vinpocetine $(3 \mathrm{mg} / \mathrm{kg})$, cinnarizine $(7$ $\mathrm{mg} / \mathrm{kg})$, pyritinol $(55 \mathrm{mg} / \mathrm{kg})$, or rosiglitazone $(0.5 \mathrm{mg} / \mathrm{kg})$, showed a significant increase in brain SOD and GSH in ischaemic rats and restored the reduced brain SOD and GSH to the sham-operated value. Brain SOD activity was $62.5 \pm 7.78,55.8 \pm 7.7,60.7 \pm 7$, $60.7 \pm 10.2 \mathrm{u} / \mathrm{g}$ respectively and Brain GSH activity was $55 \pm 11.3,40.1 \pm 16.5$, $38.8 \pm 7.2, \quad 48.8 \pm 12.6 \mu \mathrm{mol} / \mathrm{g}$ respectively (table1).

2. Effect on brain malondialdhyde (MDA) content:

The results of the present study revealed that, ischaemia/reperfusion showed a significant increase in brain MDA content compared to the shamoperated group. Brain MDA content was $70.3 \pm 18.6 \mathrm{nmol} / \mathrm{g}$ in the ischaemic group vs $45.8 \pm 18.6 \mathrm{nmol} / \mathrm{g}$ in the shamoperated group. Administration of vinpocetine (3 $\mathrm{mg} / \mathrm{kg})$, pyritinol (55 $\mathrm{mg} / \mathrm{kg})$, or rosiglitazone $(0.5 \mathrm{mg} / \mathrm{kg})$, reduced the elevated brain MDA content to the sham-operated value. Brain MDA content was $47.1 \pm 19.9,51.98 \pm 10.7$, $48.9 \pm 9.7 \mathrm{nmol} / \mathrm{g}$ respectively. (table 1 ).

Table (1): Effect of vinpocetine, cinnarizine, pyritinol, and rosiglitazone on the activity of brain SOD, GSH, and MDA contents:

\begin{tabular}{|c|c|c|c|}
\hline Parameters & $\begin{array}{l}\text { Brain SOD } \\
\quad(\mathrm{u} / \mathrm{g})\end{array}$ & Brain GSH $(\mu \mathrm{mol} / \mathrm{g})$ & $\begin{array}{c}\text { Brain MDA } \\
\text { (nmol/g) }\end{array}$ \\
\hline Sham & $44.6 \pm 5.1$ & $38.1 \pm 14.4$ & $45.8 \pm 18.6$ \\
\hline Ischaemic & $28.9 \pm 4.3^{@}$ & $22.1 \pm 6.5^{@}$ & $70.3 \pm 18.6^{@}$ \\
\hline Vinpocetine $(3 \mathrm{mg} / \mathrm{kg})$ & $62.5 \pm 7.78^{*}$ & $55 \pm 11.3^{*}$ & $47.1 \pm 19.9^{*}$ \\
\hline Cinnarizine $(7 \mathrm{mg} / \mathrm{kg})$ & $55.8 \pm 7.7^{*}$ & $40.1 \pm 16.5^{*}$ & $68.6 \pm 9.38$ \\
\hline Pyritinol $(55 \mathrm{mg} / \mathrm{kg})$ & $60.7 \pm 7^{*}$ & $38.8 \pm 7.2^{*}$ & $51.98 \pm 10.7$ \\
\hline Rosiglitazone $(0.5 \mathrm{mg} / \mathrm{kg})$ & $60.7 \pm 10.2^{*}$ & $48.8 \pm 12.6^{*}$ & $48.9 \pm 9.7^{*}$ \\
\hline
\end{tabular}

Data are presented as mean \pm S.D, $n=7$

@ Significantly different from the sham-operated group at $p<0.05$.

* Significantly different from the ischaemic group at $p<0.05$.

3. Effect on the activity of serum catalase (CAT) level:

Ischaemia/reperfusion injury in rats caused a significant decrease in the activity of serum CAT compared to the sham- operated group. Serum CAT level was $34.3 \pm 4.7 \mathrm{u} / 1$ in the ischaemic group vs $74.9 \pm 16.9 \mathrm{u} / 1$ in the sham-operated group. Administration of vinpocetine ( $3 \mathrm{mg} / \mathrm{kg}$ ), pyritinol $(55 \mathrm{mg} / \mathrm{kg})$, or rosiglitazone $(0.5$ 
$\mathrm{mg} / \mathrm{kg}$ ), showed a significant increase in serum CAT activity compared to ischaemic group and was able to restore the reduced CAT level to the sham- operated value. Serum CAT level was 60.9 $\pm 24.7,56.7 \pm 19.1,72.2 \pm 36.4 \mathrm{u} / \mathrm{l}$ respectively (Fig. 1).

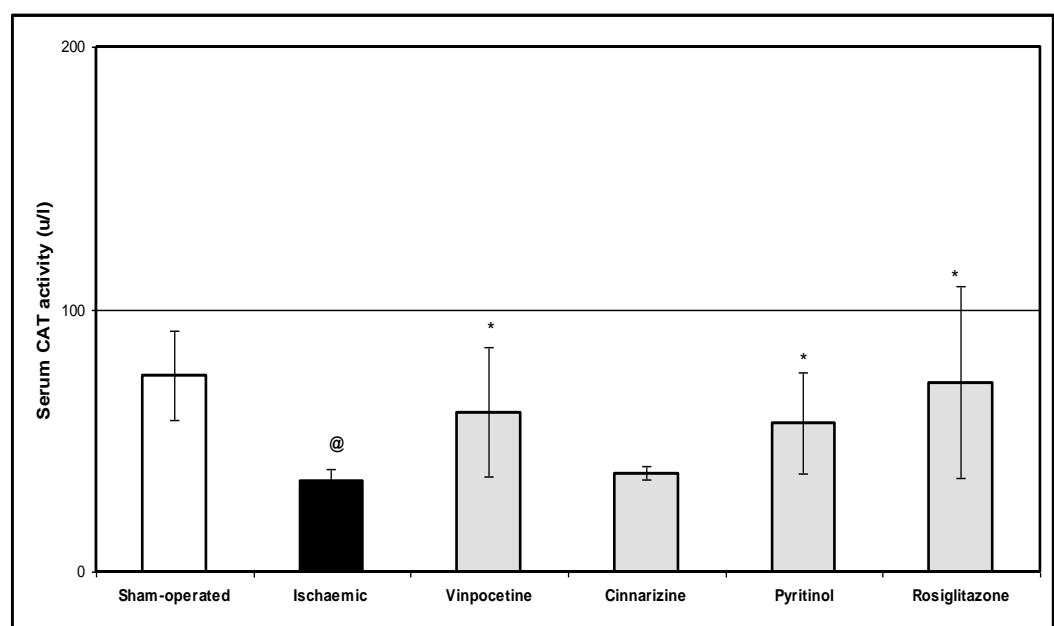

Fig, (1): Effect of vinpocetine, cinnarizine, pyritinol, and rosiglitazone, on serum CAT level: Data are presented as mean \pm S.D, $n=7$

@ Significantly different from the sham-operated group at $p<0.05$.

* Significantly different from the ischaemic group at $p<0.05$.

4. Effect on serum nitric oxide (NO) level:

Rats subjected to ischaemia/ reperfusion had a significant increase in serum NO level compared to the shamoperated group. Serum NO level was $59.1 \pm 13.6 \mathrm{nmol} / \mathrm{l}$ in the ischaemic group vs $13.5 \pm 2.7 \mathrm{nmol} / \mathrm{l}$ in the sham-operated group. The administration of vinpocetine $(3 \mathrm{mg} / \mathrm{kg})$, or rosiglitazone $(0.5 \mathrm{mg} / \mathrm{kg})$, showed a significant decrease in serum NO level compared to ischaemic group. Serum NO level was $43.7 \pm 13.98,21.3 \pm$ $6.7 \mathrm{nmol} / \mathrm{l}$ respectively (Fig. 2).

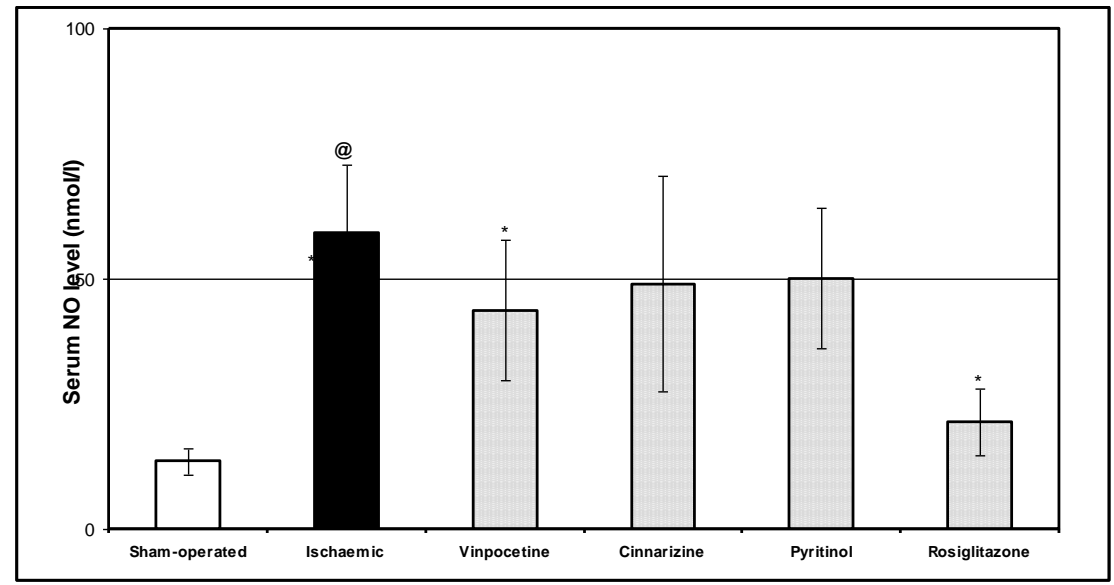

Fig, (2): Effect of vinpocetine, cinnarizine, pyritinol, and rosiglitazone on serum NO level: Data are presented as mean \pm S.D, $n=7$

@ Significantly different from the sham-operated group at $p<0.05$.

* Significantly different from the ischaemic group at $p<0.05$.

5. Effect on the activity of serum lactate dehydrogenase (LDH) and glucose-6-phosphate dehydrogenase (G6PDH) levels:

$$
\text { Rats subjected to }
$$

ischaemia/reperfusion had a significant increase in the activity of serum LDH and G6PDH compared to the shamoperated group. Serum LDH level was $590 \pm 74.1 \mathrm{u} / \mathrm{l}$ in the ischaemic group vs $339.3 \pm 63.8 \mathrm{u} / 1$ in the sham-operated group and Serum G6PDH level was 
$0.139 \pm 0.05 \mathrm{mu} / \mathrm{ml}$ in the ischaemic group vs $0.075 \pm 0.017 \mathrm{mu} / \mathrm{ml}$ in the sham-operated group. Administration of vinpocetine $(3 \mathrm{mg} / \mathrm{kg})$, cinnarizine (7 $\mathrm{mg} / \mathrm{kg}$ ), pyritinol (55 $\mathrm{mg} / \mathrm{kg})$, or rosiglitazone $(0.5 \mathrm{mg} / \mathrm{kg})$, showed a significant decrease in serum LDH activity compared to ischaemic group. Rosiglitazone administration reduced the elevated serum LDH to sham-operated value. Serum LDH level was $426 \pm 64.3$, $404 \pm 76,465 \pm 108.7,379.3 \pm 82.7 \mathrm{u} / 1$ respectively (Fig. 3). The previous drugs also significantly reduced the elevated serum G6PDH level in ischaemic rats except pyritinol where there was no significant change. Serum G6PDH level was $0.081 \pm 0.013,0.067 \pm 0.017,0.079$ $\pm 0.008 \mathrm{mu} / \mathrm{ml}$ respectively (Fig. 4).

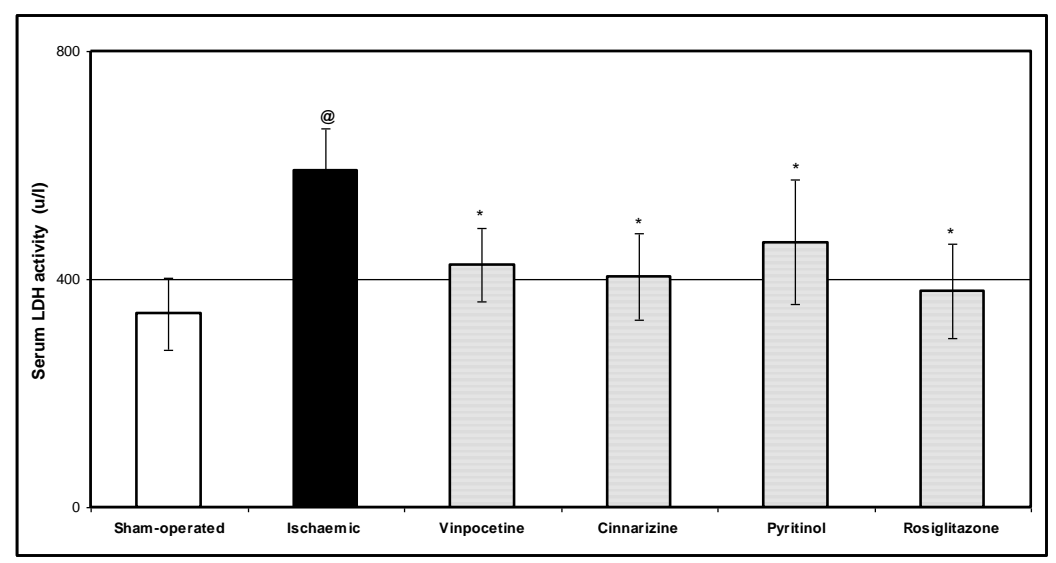

Fig, (3): Effect of vinpocetine, cinnarizine, pyritinol, and rosiglitazone on serum LDH level: Data are presented as mean \pm S.D, $n=7$

@ Significantly different from the sham-operated group at $p<0.05$.

* Significantly different from the ischaemic group at $p<0.05$.

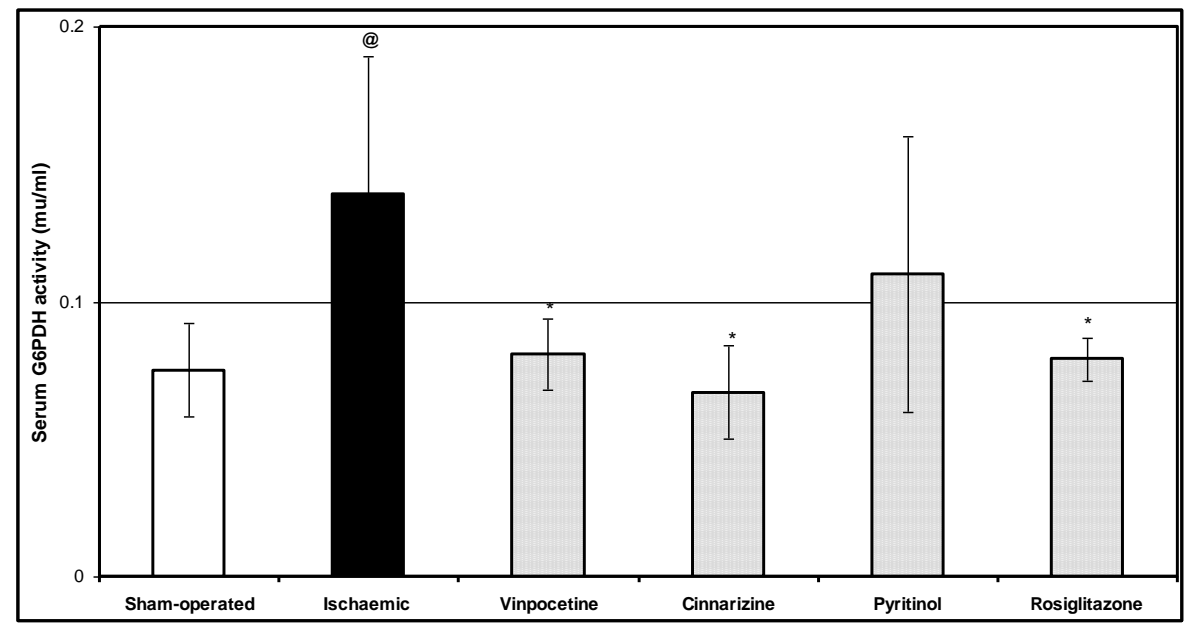

Fig, (4): Effect of vinpocetine, cinnarizine, pyritinol, and rosiglitazone, on serum G6PDH level:

Data are presented as mean \pm S.D, $n=7$

@ Significantly different from the sham-operated group at $p<0.05$.

* Significantly different from the ischaemic group at $p<0.05$.

\section{DISCUSSION}

In the present study, rats subjected I/R showed a significant decrease in brain SOD and GSH contents as well as serum CAT activity. During reperfusion, these endogenous antioxidative defenses are likely to be ineffective. The perturbation of the antioxidant defense mechanisms during reperfusion may be summarized as the result of overproduction of oxygen radicals 
by cytosolic pro-oxidant enzymes and mitochondria, inactivation of detoxification systems, consumption and degradation of antioxidants, and failure to adequately replenish antioxidants in ischaemic brain tissue (Sugawara et al., 2002; and Chen et al., 2014). The reduction in SOD level as a result of $I / R$ injury is in agreement with the study of Homi et al. (2002) who demonstrated that SOD activity was reduced in all brain regions following $\mathrm{I} / \mathrm{R}$ injury, also they demonstrated that in the earlier of ischaemia reperfusion there is a condition that predisposes hippocampus and striatum to oxidative damage, that cause a decrease in the activities of both catalase and SOD, thus may lead to extensive and latter damage. Tokuda et al. (1993) suggested that hydrogen peroxide, which is the dismutation product of superoxide anions, may inactivate SOD with a modification in histidine residue located in the active site of the enzyme. In the current work, GSH content was significantly reduced due to ischaemic insult. This could be explained by the consumption of GSH due to scavenging of the rapidly generated reactive oxygen species following ischaemia (Al-Majed et al., 2006).The decrease in GSH level in the present work is supported by the study of Khan et al. (2009) who reported that bilateral common carotid artery occlusion causes neural damage by overproduction of free radicals, which might cause oxidative damage to the lipid and protein cell membrane. Therefore, it ultimately leads to a decrease in GSH content and activation of antioxidant enzymes. The observed reduction in CAT level as a result of $I / R$ injury is in agreement with other previous studies which demonstrated a decrease in the enzyme activity after transient forebrain ischaemia gerbil model (Yokoyama et al., 2004).

The decrease in CAT activity in the present study may be explained by the attack of ROS to the active site of the enzyme as reported by Homi et al., (2002).
The results also showed that, brain MDA was significantly elevated in ischaemic rats, which might reflect increased ROS generation and/or decreased destruction. Brain tissue is highly susceptible to oxidative damage because of its high oxygen consumption, its high concentrations of polyunsaturated fatty acids (PUFAs), which are the prime targets for free radical attack, its high content of iron and its low levels of antioxidants (Floyd \& Carney, 1992; and Skrzydlewska et al., 1998).

The present study revealed that, NO level was significantly increased due to ischaemic insult. Rao et al. (1998) reported that NO level increased rapidly in traumatic brain injury and in global transient cerebral ischaemia in gerbils. The rapid increase in NO production during ischaemia is expected to be due to activation of the constitutive forms of NOS (nNOS and eNOS). However, constitutive forms of NOS produce small amounts NO in short time (Malinski et al., 1993; and Wei et al., 1999). Further NO production is caused by iNOS hyperactivity as the enzyme is potently activated by the release of inflammatory mediators such as interleukin $1 \beta$ and tumor necrosis factor alpha (TNF $\alpha)$ (Gonález-Correa et al., 2006).

Results of the present work showed that $\mathrm{I} / \mathrm{R}$ injury significantly increased serum LDH and G6PDH. These findings confirm the previously reported increase in LDH concentration after focal cerebral I/R (Rastogi et al., 2006; and Helps \& Sims, 2007) and global I/R (Levy et al., 2004). Zhao et al. (2012) demonstrated that G6PDH increases as a result of I/R injury at the early reperfusion period (1-24 hr) following global cerebral ischaemia in rats. They also demonstrated that, cerebral ischaemia might be able to shunt glucose metabolism into the pentose phosphate pathway by inhibition of aerobic glycolysis thus leading to an increase in G6PDH activity. 
This study revealed that vinpocetine significantly restored the reduced brain SOD and GSH and serum CAT to the sham-operated value. It also decreased the elevated brain MDA, and serum NO, LDH, G6PDH levels in ischaemic rats. These findings are in agreement with the study of Deshmukh et al. (2009) who reported that vinpocetine significantly reduced oxidative stress, and restored the reduced GSH level after experimental oxidative stress in rats. They also revealed that vinpocetine significantly reduced the oxidative-nitritive stress, as evidenced by the decrease in MDA and nitrite levels. Vinpocetine has been demonstrated to have antioxidant potential and to scavenge hydroxyl radicals (Santos et al., 2000; and Pereira et al., 2003). It has been reported that vinpocetine improves cerebral blood flow perhaps by elevating cGMP levels (Kruuse et al., 2001), improves mitochondrial function (Tárnok et al., 2008), improves oxygen and glucose utilization of whole brain (Shibota et al., 1982), thereby restoring cerebral energy balance, thus the effect of vinpocetine on the elevated G6PDH level may be attributed to restoring the cerebral energy level and glucose utilization. Vinpocetine may exert its neuroprotective effect by modulating oxidative stress (Jayakumar et al., 2002). It can also exert its neuroprotective effect by an antiinflammatory action ((Imbimbo, 2004; and Hirsch \& Hunot, 2009).

Cinnarizine is a selective $\mathrm{Ca}^{2+}$ channel blocker widely used in the treatment of cerebral and vascular insufficiency (Singh et al., 1985). The present study demonstrated that cinnarizine treatment significantly restored the reduced brain GSH in ischaemic rats to the shamoperated value. This observation is in agreement with the study of Serrano et al. (2005) who observed increased GSH/GSSG ratio in the striatum of female parkin knock-out mice. Cinnarizine a diphenyl piperazine derivative may exert its antioxidant effect due to its capacity to concentrate in the lipid bilayer thus protects membrane phospholipids against oxidative injury (Gonçalves et al., 1991). Thus the neuroprotective effect of cinnarizine in our study may be attributed to its antioxidant effect and this is confirmed by the increase in brain GSH and SOD contents. However, it couldn't affect either serum CAT level or brain MDA content and this observation is in agreement with previous studies mentioned that cinnarizine couldn't affect MDA production at any concentration after mitochondrial swelling induced by high $\mathrm{Ca}^{2+}$ intake (Elimadi, et al., 1998). LDH and G6PDH levels were significantly reduced by cinnarizine treatment. This may be attributed to inhibition in hexose monophsphate level and improvement of glycolysis that reduces the influence of ischaemia on energy metabolism (Ciancarelli et al., 2004)

The present study showed that Pyritinol significantly increased GSH, SOD, and CAT levels. This effect may be attributed to its antioxidant effect. Many previous studies have demonstrated the scavenger properties of pyritinol. It could significantly reduce free radicals after oxidative stress induced by streptozotocin in diabetic rats. Pyritinol could reduce 4 damage markers; namely free carbonyls, dityrosine, malondialdhyde, and advanced oxidative protein products (JiménezAndrade et al., 2008), and it protected cell proteins by scavenging free radicals in vitro (Pavlík and Pilař., 1989). Also it significantly reduced brain MDA content in ischaemic rats (Jiménez-Andrade et al., 2008). Serum LDH was also reduced by pyritinol treatment. It was demonstrated that pyritinol possessed significant hydroxyl free radical scavenger activity in vitro (Pavlík and Pilař., 1989). Therefore, it could protect cartilage and synovial protein against free radical induced degradation (Wolff et al., 1986). The same line of reasoning may be applied to some cases of stroke or brain trauma, where the generation of hydroxyl free radicals by reactive iron/oxygen radical complexes is 
abundant (Halliwell and Gutteridge, 1986). Based on these results, we can suggest that the antioxidant effect of pyritinol by its scavenging properties may provide a neuroprotection activity against I/R injury.

Rosiglitazone, the most potent PPAR- $\gamma$ agonist significantly restored the reduced brain GSH, SOD and serum CAT activity to the sham-operated value. These findings are consistent with other previous studies (Villegas et al., 2004; Collino et al., 2006; and $\mathrm{Yu}$ et al., 2008). It significantly reduced brain MDA. This observation is in accordance with the study of Collino et al., (2006) who indicated that rosiglitazone inhibite lipid peroxidation after global cerebral I/R. Also our results indicated that rosiglitazone significantly reduced $\mathrm{LDH}$ level and this observation is in accordance with the study of Sener et al. (2007) who observed that LDH level was reduced after treatment of remote organs subjected to burn-induced oxidative injury with rosiglitazone. The present study also demonstrated that rosiglitazone reduced the elevated nitrite level in ischaemic rats and this observation is supported by the study of Collino et al. (2006) who demonstrated that iNOS protein expression that responsible for excessive NO production during brain $\mathrm{I} / \mathrm{R}$ injury was down-regulated by treatment with pioglitazone and rosiglitazone.

The precise neuroprotective mechanisms of PPAR- $\gamma$ agonists have not yet been fully clarified. Many studies have demonstrated that rosiglitazone can decrease reactive oxygen species production and lipid peroxidation confirming its ability to attenuate excessive ROS formation secondary to I/R injury. Thus rosiglitazone may exert its neuroprotective effect against $\mathrm{I} / \mathrm{R}$ by reduction of oxidative stress (Collino et al., 2006). Aoun et al. (2003) demonstrated that the pre-treatment with PPAR- $\gamma$ agonists protected an immortalized mouse hippocampal cell line against oxidative stress induced by glutamate or hydrogen peroxide. Furthermore, Yu et al. (2008) reported that rosiglitazone has antioxidative stress in epilepsy model by decreasing ROS production and lipid peroxidation in rats subjected to oxidative stress following pilocarpine-induced status epilepticus. Moreover, there was elevated superoxide content and exacerbated mitochondrial damage in PPAR- $\gamma$ knockout mice (Ding et al., 2007). Furthermore, Şener et al. (2007) suggested that rosiglitazone may be protective against burn-induced oxidative injury by inhibiting neutrophil infiltration, and subsequent activation of inflammatory mediators that induce lipid peroxidation. Several studies have reported the anti-inflammatory effect of PPAR- $\gamma$ agonists in animal models of ischaemia, such as myocardial infarction (Yue et al., 2001; and Wayman et al., 2002), renal I/R injury (Sivarajah et al., 2003) and ischaemic lung injury (Ito et al., 2004). Thus, the antiinflammatory properties of rosiglitazone can play an important role in neuroprotection against I/R injury.

\section{CONCLUSION}

Cerebral $\mathrm{I} / \mathrm{R}$ injury resulted in brain damage as a result of the formation of ROS such as NO and superoxide and the impairment of enzymatic defense mechanism such as GSH, SOD, and CAT, which resulted in tissue oxidative stress and impairment of brain energy metabolism as evidence by elevation of LDH and G6PDH levels. Vinpocetine and PPAR- $\gamma$ agonist rosiglitazone are potent neuroprotective agents against experimental brain I/R injury in rats. They were able to ameliorate the damaged effect of cerebral $\mathrm{I} / \mathrm{R}$ injury thereby attenuating oxidative stress in ischaemic rats. Cinnarzine and pyritinol showed a marked neuroprotective activity but less than the previous drugs.

\section{ACKNOWLEDGEMENTS}

I wish to express thanks to Dr. Waleed Barakat; Lecturers of Pharmacology, Faculty of Pharmacy, Zagazig University; for helping and supplying me with advice

\section{REFERENCES}

1. Abd-El-Gawad, H.M. and El-Sawalhi, M.M. (2004): Nitric oxide and 
oxidative stress in brain and heart of normal rats treated with doxorubicin: role of aminoguanidine. J. Biochem. Mol. Toxicol., 18(2): 69-77.

2. Ahmed, S.H.; Shaikh, A.Y.; Shaikh, Z. and Hsu, C.Y. (2000): What animal models have taught us about the treatment of acute stroke and brain protection. Curr. Atheroscler. Rep., 2: 167-180.

3. Al-Majed, A.A.; Al-Omar, F.A. and Nagi, M.N. (2006): Neuroprotective effects of thymoquinone against transient forebrain ischemia in the rat hippocampus. Eur. J. Pharmacol., 543: 40-47.

4. Aoun, P.; Watson, D.G. and Simpkins, J.W. (2003): Neuroprotective effects of PPARgamma agonists against oxidative insults in HT-22 cells. Eur. J. Pharmacol., 472: 65-71.

5. Bönöczk, P.; Gulyas, B.; Adam-Vizi, V.; Nemes, A.; Karpati, E.; Kiss, B.; Kapas, M.; Szantay, C.; Koncz, I.; Zelles, T. and Vas, A. (2000): Role of sodium channel inhibition in neuroprotection: effect of vinpocetine. Brain Res. Bull., 53: 245-54.

6. Calkin, A.C.; Forbes, J.M.; Smith, C.M.; Lassila, M.; Cooper, M.E.; Jandeleit-Dahm, K.A. and Allen, T.J. (2005): Rosiglitazone attenuates atherosclerosis in a model of insulin insufficiency independent of its metabolic effects. Arterioscler. Thromb. Vasc. Biol., 25: 1903-1909.

7. Chen, L.F.; Tian, Y.F.; Lin, C.H.; Huang, L.Y.; Niu, K.C. and Lin, M.T. (2014): Repetitive hyperbaric oxygen therapy provides better effects on brain inflammation and oxidative damage in rats with focal cerebral ischemia. J. Formos. Med. Assoc., 113(9): 620-628.

8. Ciancarelli, I.; Tozzi-Ciacarelli, M.G.; Di Massimo, C.; Marini, C. and Carolei, A. (2004): Flunarizine effects on oxidative stress in migraine patients. Cephalalgia, 24: 528-532.

9. Collino, M.; Aragno, M.; Mastrocola, R.; Gallicchio, M.; Rosa, A.C.;
Dianzani, C.; Danni, O.; Thiemermann, C. and Fantozzi, R. (2006): Modulation of the oxidative stress and inflammatory response by PPAR- $\gamma$ agonists in the hippocampus of rats exposed to cerebral ischemia/ reperfusion. Eur. J. Pharmacol., 530: 70-80.

10. De Haan, H.H.; Van Reempts, J.L.; Borgers, M.; De Haan, J.; Vles, J.S. and Hasaart, T.H. (1993): Possible neuroprotective properties of flunarizine infused after asphyxia in fetal lambs are not explained by effects on cerebral blood flow or systemic blood pressure. Pediatr. Res., 34: 379384.

11. Deshmukh, R.; Sharma, V.; Mehan, S.; Sharma, N. and Bedi, K.L. (2009): Amelioration of intracerebroventricular streptozotocin induced cognitive dysfunction and oxidative stress by vinpocetine -- a PDE1 inhibitor. Eur. J. Pharmacol., 620: 49-56.

12. Dietrich, W.D. (1998): neurobiology of stroke. In: "Internatuional review of neurobiology". (Bradley, R.; Harris, A.A. and Jenner, P.), eds., Academic Press, Vol.44, p. 60.

13. Ding, G.; Fu, M.; Qin, Q.; Lewis, W.; Kim, H.W.; Fukai, T.; Bacanamwo, M.; Chen, Y.E.; Schneider, M.D.; Mangelsdorf, D.J.; Evans, R.M. and Yang, Q. (2007): Cardiac peroxisome proliferator-activated receptor $\gamma$ is essential in protecting cardiomyocytes from oxidative damage. Cardiovasc. Res., 76: 269-279.

14. Donnan, G.A.; Fisher, M.; Macleod, M. and Davis, S.M. (2008): Stroke. Lancet, 371: 1612-1623.

15. Dugan, L.L. and Choi, D.W. (1999): Hypoxic-ischemic brain injury and oxidative stress. In: "Basic Neurochemistry: Molecular, Cellular and Medical aspects". (Siesgel, G.J.; Agranoff, B.W.; Albers, R.W.; Fisher, S.K. and Uhler, M.D.), eds., Sixth edition, Lippincott Williams and Wilkins, Philadelphia, p. 711. 
16. Elimadi, A.; Bouillot, L.; Sapena, R.; Tillement, J.P. and Morin, D. (1998): Dose-related inversion of cinnarizine and flunarizine effects on mitochondrial permeability transition. Eur. J. Pharmacol., 348: 115-121.

17. Fahmi, H.; Di Battista, J.A.; Pelletier, J.P.; Mineau, F.; Ranger, P. and MartelPelletier, J. (2001): Peroxisome proliferator-activated receptor- $\gamma$ activators inhibit interleukin-1 $\beta$-induced nitric oxide and matrix metalloproteinase 13 production in human chondrocytes. Arthritis Rheum., 44: 595-607.

18. Floyd, R.A. and Carney, J.M. (1992): Free radical damage to protein and DNA: mechanisms involved and relevant observations on brain undergoing oxidative stress. Ann. Neurol., 32: S22-S27

19. Frosch, M.P.; Anthony, D.C. and Giralami, U.D. (2005): The central nervous system. In: "Robbins and Cotran Pathologic Basis of Diseases". (Kumar, V.; Abbas, A.K. and Fausto, N.), eds., Elsevier Saunders, Philadelphia, p. 1347.

20. Genkova-Papazova, M.; LazarovaBakarova, M. and Petkov, V.D. (1994): The 5HT-2-receptor antagonist ketanserine prevents electroconvulsive shock and clonidine-induced amnesia. Pharmacol. Biochem. Behav., 49: 849852.

21. Ginsberg, M.D. and Busto, R. (1989): Rodents models of cerebral ischemia. Stroke, 20: 1627-1642.

22. Gonález-Correa, J.A.; Arrebola, M.M.; Cansino, A.L.; Muñoz-Marín, J.; Guerrero, A.; Sánchez de la Cuesta, F. and De la Cruz, J.P. (2006): Effect of aspirin plus alpha-tocopherol on brain slices damage after hypoxiareoxygenation in rats with type 1-like diabetes mellitus. Neurosci. Lett., 400: 252-257.

23. Gonçalves, T.; Carvalho, A.P. and Oliveira, C.R. (1991): Antioxidant effect of calcium antagonists on microsomal membranes isolated from different brain areas. Eur. J. Pharmacol., 204: 315-322.

24. Gunn, A.J.; Williams, C.E.; Mallard, E.C.; Tan, W.K. and Gluckman, P.D. (1994): Flunarizine, a calcium channel antagonist, is prophylactically neuroproctective in hypoxic-ischemic encephalopathy in fetal sheep. Pediatr. Res., 35: 657-663.

25. Halliwell, B. and Gutteridge, J.M.C. (1986): Iron and free radical reactions: two aspects of antioxoidant protection. Trends Biochem. Sci., 11: 372-375.

26. Helps, S.C. and Sims, N.R. (2007): Inhibition of nitric oxide synthase with 7-nitroindazole does not modify early metabolic recovery following focal cerebral ischemia in rats. Neurochem. Res., 32: 663-670.

27. Hirsch, E.C. and Hunot, S. (2009): Neuroinflammation in Parkinson's disease: a target for neuroprotection? Lancet. Neurol., 8: 382-397.

28. Homi, H.M.; Freitas, J.J.S.; Curi, R.; Velasco, I.T. and Junior, B.A.S. (2002): Changes in superoxide dismutase and catalase activities of rat brain regions during early global transient ischemia/ reperfusion. Neurosci. Lett., 333: 37-40.

29. Imbimbo, B.P. (2004): The potential role of non-steroidal anti-inflammatory drugs in treating Alzheimer's disease. Expert. Opin. Investig. Drugs, 13: 1469-1481.

30. Ito, K.; Shimada, J.; Kato, D.; Toda, S.; Takagi, T.; Naito, Y.; Yoshikawa, T. and Kitamura, N. (2004): Protective effects of preisch-emic treatment with pioglitazone, a peroxisome proliferator- activated receptor-gamma ligand, on lung ischemiareperfusion injury in rats. Eur. J. Cardiothorac. Surg., 25: 530-536.

31. Jaiswal, A.K.; Upadhyay, S.N. and Bhattacharya, S.K. (1990). Effect of pyritinol, a cerebral protector, on learning and memory deficits induced by prenatal under nutrition and environmental impov-erishment in young rats. Indian J. Exp. Biol., 28: 609-615. 
32. Jayakumar, A.R.; Panickar, K.S. and Norenberg, M.D. (2002): Effects on free radical generation by ligands of the peripheral benzodiazepine receptor in cultured neural cells. J. Neurochem., 83: 1226-1234.

33. Jiménez-Andrade, G.Y.; Reyes-García, G.; Sereno, G.; Ceballos-Reyes, G.; Vidal-Cantu, G.C. and Granados-Soto, V. (2008): Pyritinol reduces nociception and oxidative stress in diabetic rats. Eur. J. Pharmacol., 590: 170-176.

34. Johansson, L.H. and Borg, L.A. (1988): A spectrophotometric method for determination of catalase activity in small tissue samples. Anal. Biochem., 174(1): 331-36.

35. Khan, M.M.; Ahmad, A.; Ishrat, T.; Khuwaja, G.; Srivastawa, P.; Khan, M.P.; Raza, S.; Javed, H.; Vaibhav, K.; Khan, A. and Islam, F. (2009): Rutin protects the neuronal damage induced by transient focal ischemia in rats. Brain Res., 1292: 123-135.

36. Konrad, T.; Bloechle, C.; Haller, G.; Broelsch, C.E.; Usadel, K.H. and Kusterer, K. (1995): Verapamil and flunarizine protected the isolated perfused rat liver against warm ischemia and reperfusion injury. Res. Exp. Med., 195: 61-68.

37. Kornberg, A. and Horecker, B.L. (1955): Glucose-6-phosphate dehyd-rogenase. In: "methods in enzymology". (Colowick, S.P. and Kaplan, N.O.), eds., Academic press, New York, Vol 1, pp. 323-326.

38. Kruuse, C.; Rybalkin, S.D.; Khurana, T.S.; Jansen-Olesen, I.; Olesen, J. and Edvinsson, L. (2001): The role of cGMP hydrolyzing phosphodiestrases 1 and 5 in cerebral artery dilatation. Eur. J. Pharmacol., 420: 55-65.

39. Lakhan, S.E.; Kirchgessner, A. and Hofer, M. (2009): Inflammatory mechanisms in ischemic stroke: therapeutic approaches. J. Transl. Med., 7: 97.

40. Levy, J.; Zhu, Z. and Dunbar, J.C. (2004): The effect of global brain ischemia in normal and diabetic animals: the influence of calcium channel blockers. Endocrine, 25 (2): 91-95.

41. Lo, E.H.; Dalkara, T. and Moskowitz, M.A. (2003): Mechanisms, challenges and opportunities in stroke. Nat. Rev. Neurosci., 4: 399-415.

42. Luna-Medina, R.; Cortes-Canteli, M.; Alonso, M.; Santos, A.; Martinez, A. and Perez-Castillo, A. (2005): Regulation of inflammatory response in neuronal cells in vitro by thiadiazolidinones derivatives through peroxisome proliferator-activated receptor- $\gamma$ activation. J. Biol. Chem., 280: 21 453-21 462.

43. Macdonald, R.L. and Stoodley, M. (1998): Pathophysiology of cerebral ischemia. Neurol. Med. Chir. (Tokyo), 38: 1-11.

44. Malinski, T.; Bailey, F.; Zhang, Z.G. and Chopp, M. (1993): Nitric oxide measured by a porphyrinic microsensor in rat brain after transient middle cerebral artery occlusion. J. Cereb. Blood Flow Metab., 13: 355-358.

45. Montgomery, H.A.C. and Dymock, J.F. (1961): The determination of nitrite in water. Analyst, 86: 414-416.

46. Nakajima, A.; Wada, K.; Miki, H.; Kubota, N.; Nakajima, N.; Terauchi.; Y.; Ohnishi, S.; Saubermann, L.J.; Kadowaki, T.; Blumberg, R.S.; Nagai, R. and Matsuhashi, N. (2001): Endogenous PPAR $\gamma$ mediates antiinflammatory activity in murine ischemia-reperfusion injury. Gastroenterology, 120: 460-469.

47. Nishikimi, M.; Rao, N.A. and Yogi, K. (1972): The occurrence of superoxide anion in the reaction of reduced phenazine methosulpha-teand molecular oxygyn. Biochem. Biophys. Res. Commun., 46: 849-854.

48. Okada, M.; Yan, S.F. and Pinsky, D.J. (2002): Peroxisome proliferatoractivated receptor- $\gamma$ (PPAR- $\gamma$ ) Activation suppresses ischemic induction of Egr-1 and its 
inflammatory gene targets. J. FASEB, 16: 1861-1868.

49. Pavlík, A. and Pilař, J. (1989): Protection of cell proteins against freeradical attack by nootropic drugs: scavenger effect of pyritinol confirmed by electron spin resonance spectroscopy. Neuroph-armacology, 28: 557-561.

50. Pereira, C.; Agostinho, P.; Moreira, P.I.; Durate, A.I.; Santos, M.S. and Oliveira, C.R. (2003): Neuroprotection strategies: effect of vinpocetine in vitro oxidative stress models. Acta Med. Port., 16: 401-406.

51. Pesce, A. (1984): Lactate dehydrogenase. Kaplan et al. Clin. Chem. pp, 117, 438. Mosby. St. Louis.

52. Rao, A.M.; Dogan, A.; Hatcher, J.F. and Dempsey, R.J. (1998): Fluorometric assay of nitrite and nitrate in brain tissue after traumatic brain injury and cerebral ischemia. Brain Res., 793: 265-270.

53. Rastogi, L.; Godbole, M.M.; Ray, M.; Rathore, P.; Pradhan, S.; Gupta, S.K. and Pandey, C.M. (2006): Reduction in oxidative stress and cell death explains hypothyroidism induced neuroprotection subsequent to ischemia/reperfusion insult. Exp. Neurol., 200: 290-300.

54. Santos, M.S.; Durate, A.I.; Moreira, P.I. and Oliveira, C.R. (2000): Synaptosomal response to oxidative stress: effects of vinpocetine. Free Radic. Res., 32: 57-66.

55. Seif-El-Nasr, M.; Nuglisch, J. and Krieglstein, J. (1992): Prevention of ischemic-induced cerebral hypothermia by controlling the environmental temperature. J. Pharmacol. Toxicol. Methods, 27: 23-26.

56. Şener, G.; Şehirli, A.Ö.; Gedik, N. and Dülger, G.A. (2007): Rosiglitazone, a PPAR- $\gamma$ ligand, protects against burninduced oxidative injury of remote organs. Burns, 33: 587-593.

57. Serrano, A.; Menendez, J.; Casarejos, M.J.; Solano, R.M.; Gallego, E.;
Sanchez, M.; Mena, M.A. and Garcia de Yebenes, J. (2005): Effects of cinnarizine, a calcium antagonist that produces human Parkinsonism, in parkin knock out mice. Neuropharmacology, 49: 208-219.

58. Shibota, M.; Kakihana, M. and Nagaoka, A. (1982): The effect of vinpocetine on brain glucose uptake in mice. Folia Pharmacol. Jpn, 80: 221224.

59. Singh, B.N.; Baky, S. and Nademanee, K. (1985): Second-generation calcium antagonists: search for greater selectivity and versatility. Am. J. Cardiol., 55: 214B-221B.

60. Sivarajah, A.; Chatterjee, P.K.; Patel, N.S.; Todorovic, Z.; Hattori, Y.; Brown, P.A.; Stewart, K.N.; Mota-Filipe, H.; Cuzzocrea, S. and Thiemermann, C. (2003): Agonists of peroxisomeproliferator activated receptor-gamma reduce renal ischemia/reperfusion injury. Am. J. Nephrol., 23: 267-276.

61. Skrzydlewska, E.; Witek, A. and Farbiszewski, R. (1998): The comparison of the antioxidant defense potential of brain to liver of rats after methanol ingestion. Comp. Biochem. Physiol. C. Pharmacol. Toxicol. Endocrinol., 120(2): 289-294.

62. Sorg, D.A. and Buckner, B. (1964): A simple method of obtaining venous blood from small laboratory animals. Proc. Soc. Exp. Biol. Med., 115: 11311132.

63. Stoppe, G.; Sandholzer, H.; Staedt, J.; Kiefer, J.; Winter, S.; Kochen, M.M. and Rüther, E. (1995): Factors influencing the prescribing of nootropic drugs. Results of a representative inquiry in lower Saxony. Dtsch. Med. Wochenschr., 120 (47): 1614-1619.

64. Sugawara, T.; Noshita, N.; Lewen, A.; Gasche, Y.; Ferrand-Drake, M.; Fujimura, M.; Morita-Fujimura, Y. and Chan, P.H. (2002): Overexpression of copper/zinc superoxide dismutase in transgenic rats protects vulnerable 
neurons against ischemic damage by blocking the mitochondrial pathway of caspase activation. J. Neurosci., 22: 209217.

65. Tárnok, K.; Kiss, E.; Luiten, P.G.; Nyakas, C.; Tihanyi, K.; Schlett, K. and Eisel, U.L. (2008): Effects of vinpocetine on mitochondrial function and neuroprotection in primary cortical neurons. Neurochem. Int., 53: 289-295.

66. Tokuda, Y.; Uozumi, T. and Kawasaki, T. (1993): The superoxide dismutase activities of cerebral tissues, assayed by the chemiluminescence method, in the gerbil focal ischemia/reperfusion and global ischemia models. Neurochem. Int., 23: 107-114.

67. Toledano, A. and Bentura, M.L. (1994): Pyritinol facilitates the recovery of cortical cholinergic deficits caused by nucleus basalis lesions. J. Neural Transm. Park. Dis. Dement. Sect., 7: 195-209.

68. Traystman, R.J. (2003): Animal models of focal and global cerebral ischemia. ILAR J., 44(2): 85-95.

69. Tretter, L. and Adam-Vizi, V. (1998): The neuroprotective drug vinpocetine prevents veratridine-induced $[\mathrm{Na}+] \mathrm{i}$ and $[\mathrm{Ca} 2+] \mathrm{i}$ rise in synaptosomes. Neuroreport, 9: 1849-1853.

70. Uchiyama, M. and Mihara, M. (1978): Determination of malona-ldehyde precursor in tissues by thiobarbituric acid test. Anal. Biochem., 86 (1): 271278.

71. Vanella, A.; Sorrenti, V.; Gambera, G.; Castorina, C.; Di Giacomo, C.; Campisi, A.; Salva, M. and Perez-Polo, J.R. (1990): Lipid peroxidation in rat cerebral cortex during post-ischemic reperfusion: effect of exogenous antioxidants and $\mathrm{Ca}(++)-$ antagonist drugs. Ital. J. Biochem., 39: 196A-198A.

72. Vas, A. and Gulyás, B. (2005): Eburnamine derivatives and the brain. Med. Res. Rev., 25: á737-757.

73. Villegas, I.; Martin, A.R.; Toma, W. and de la Lastra, C.A. (2004): Rosiglitazone, an agonist of peroxisome proliferator- activated receptor gamma, protects against gastric ischemia-reperfusion damage in rats: role of oxygen free radicals generation. Eur. J. Pharmacol., 505: 195203.

74. Wayman, N.S.; Ellis, B.L. and Thiemermann, C. (2002): Ligands of the peroxisome proliferator-activated receptor-PPAR- $\alpha$ reduce myocardial infarct size. Med. Sci. Monit., 8: BR243-247.

75. Wei, G.; Dawson, V.L. and Zweier, J.L. (1999): Role of neuronal and endothelial nitric oxide synthase in nitric oxide generation in the brain following cerebral ischemia. Biochim. Biophys. Acta, 1455(1): 23-34.

76. Wolff, S.P.; Garner, A. and Dean, R.T. (1986): Free radicals, lipids and protein degradation. Trends Biochem. Sci., 11: 27-31.

77. Yokoyama, K.; Shimada, Y.; Hori, E.; Nakagawa, T.; Takagi, S.; Sekiya, N.; Kouta, K.; Nishijo, H.; Yokozawa, T. and Terasawa, K. (2004): Effects of Choto-san and hooks and stems of Uncaria sinensis on antioxidant enzyme activities in the gerbil brain after transient forebrain ischemia. J. Ethnopharmacol., 95: 335-343.

78. Yu, X.; Shao, X.G.; Sun, H.; Li, Y.N.; Yang, J.; Deng, Y.C. and Huang, Y.G. (2008): Activation of cerebral peroxisome proliferator-activated receptors gamma exerts neuroprotection by inhibiting oxidative stress following pilocarpineinduced status epilepticus. Brain Res., 1200: 146-158.

79. Yue, T.L.; Chen, J.; Bao, W.; Narayanan, P.K.; Bril, A.; Jiang, W.; Lysko, P.G.; Gu, J.L.; Boyce, R.; Zimmerman, D.M.; Hart, T.K.; Buckingham, R.E. and Ohlstein, E.H. (2001): In vivo myocardial protection from ischemia/reperfusion injury by the peroxisome proliferator-activated receptor- $\gamma$ agonist rosiglitazone. Circulation, 104: 2588-2594.

80. Zhao, G.; Zhao, Y.; Wang, X. and Xu, Y. (2012): Knockdown of glucose-6- 


$\begin{array}{llll}\text { phosphate } & \text { dehydrogenase } & \text { (G6PD) } & \text { reperfusion: the pros and cons. } \\ \text { following } & \text { cerebral } & \text { ischemic } & \text { Neurochem. Int., 61: 146-155. }\end{array}$

\section{بعض التأثيرات الحيوية لعقاقير معينة فى حالة نقص دموية المخ المستحدثة تجريبا

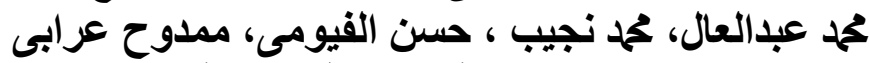

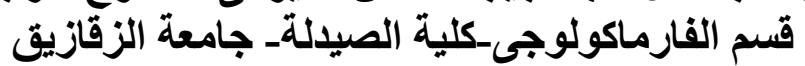

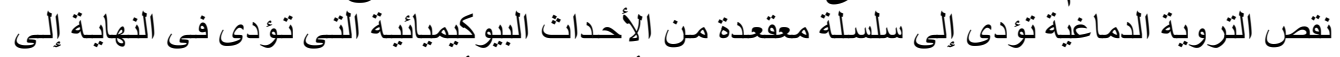

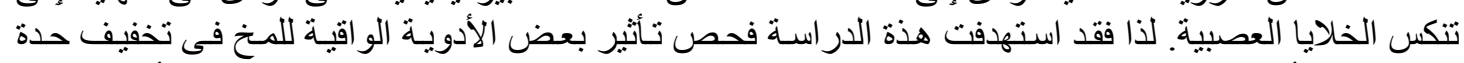

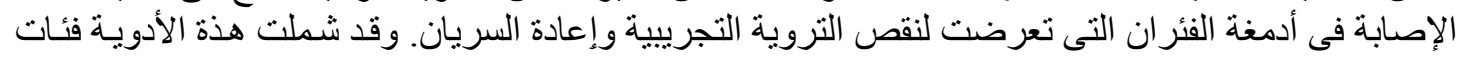

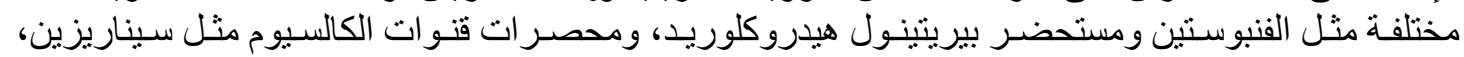

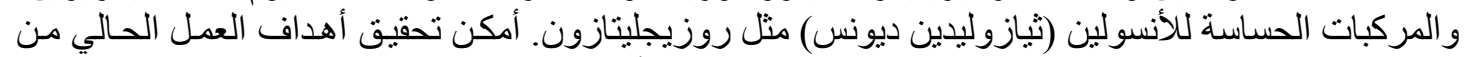

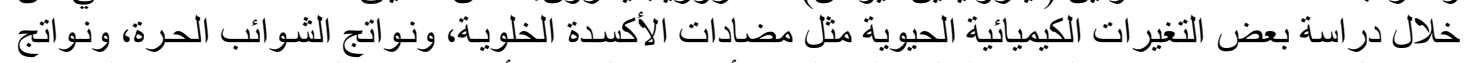

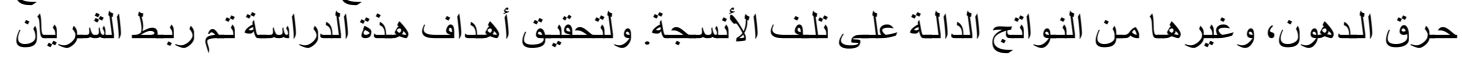

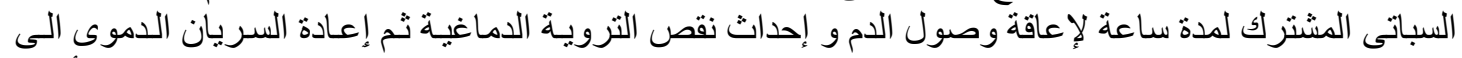

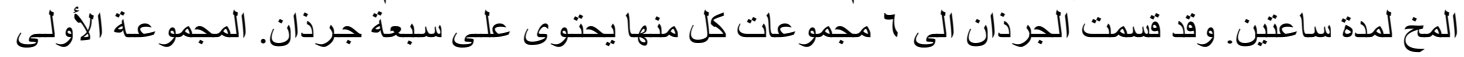

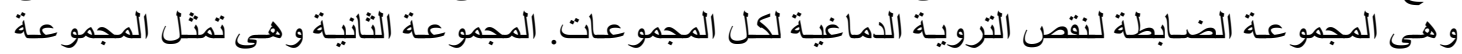

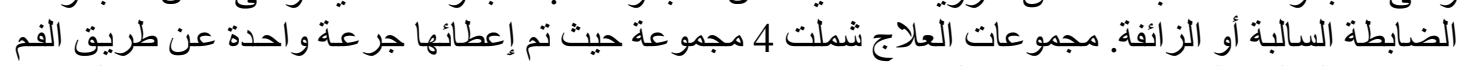

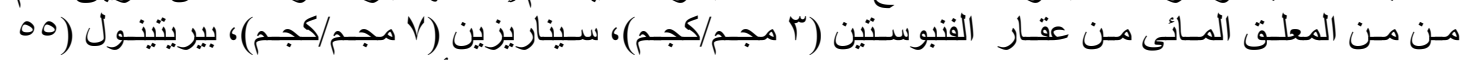

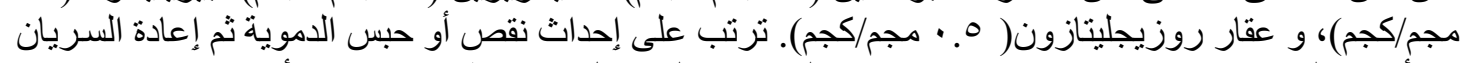

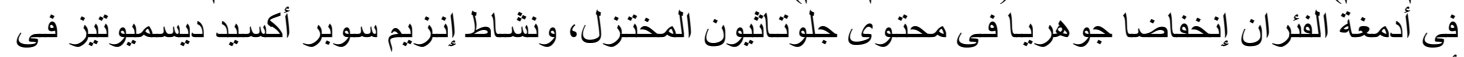

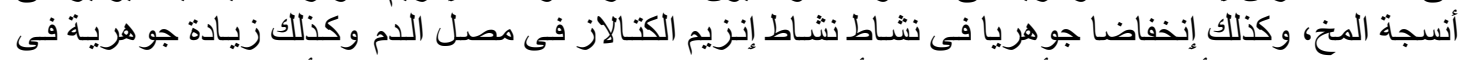

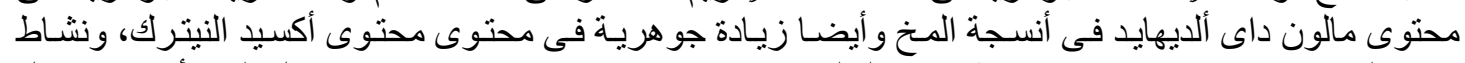

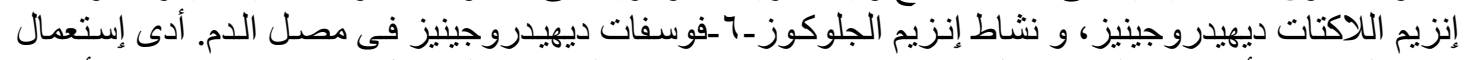

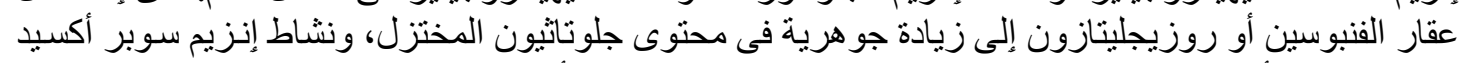

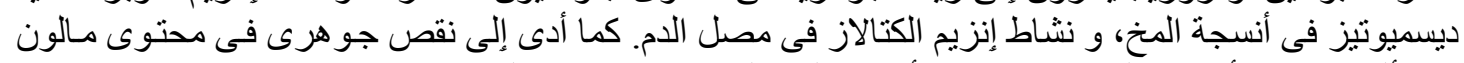

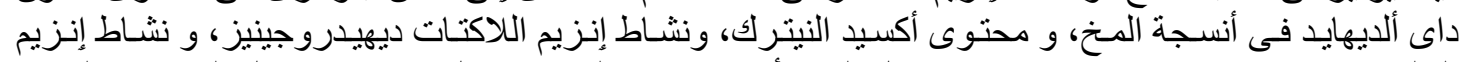

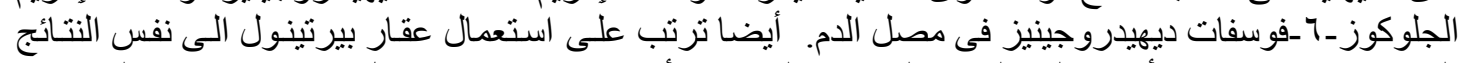

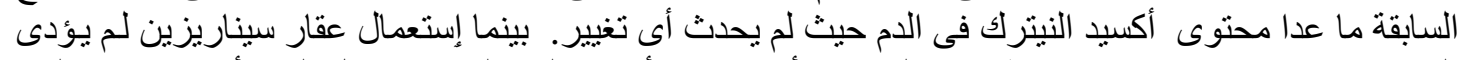

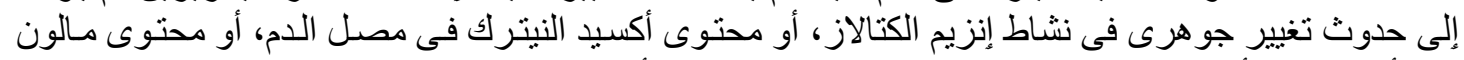

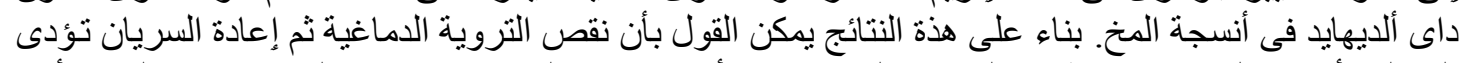

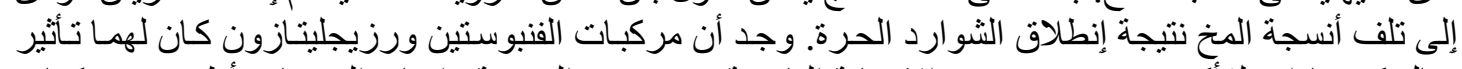

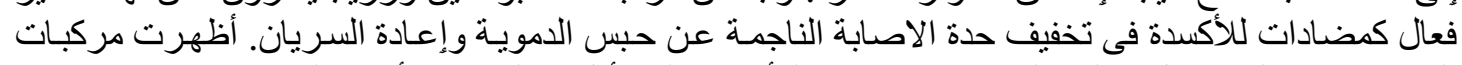
السيناريزين و البيرتينول فعالية ملحوظة كمضادات للأكسدة ولكن أقل فاعلية من الأدوية السابقة. 